\title{
HUBUNGAN PENGGUNAAN ANTIBIOTIK DENGAN TINGKAT KEKAMBUHAN ISPA PADA BALITA DI PUSKESMAS CILEMBANG KOTA TASIKMALAYA PERIODE 1 JANUARI - 31 DESEMBER 2016
}

\author{
Silka Reslia Riswanto', Dyah Retnani Basuki ${ }^{1}$, Muhammad Fadhol Romdhoni ${ }^{1}$ \\ ${ }^{1}$ Fakultas Kedokteran Universitas Muhammadiyah Purwokerto
}

\author{
Email : fadhol.romdhoni@gmail.com
}

\begin{abstract}
ABSTRAK
Latar Belakang: Antibiotik adalah zat atau bahan yang digunakan untuk mencegah dan mengobati suatu infeksi karena bakteri. Di negara Amerika Serikat terdapat 50 juta resep antibiotik yang tidak diperlukan dari 150 juta resep setiap tahunnya penggunaan antibiotik terus meningkat yang menyebabkan antara lainpenggunaan obat yang tidak tepat akan menimbulkan banyak masalah segi efektivitas, efek samping, interaksi, ekonomi dan penyalahgunaan obat, sehingga memberikan banyak dampak negatif antara lain mutu dan pengelolaan pelayanan obat, resistensi obat, efek samping pada pasien, alergi bagi pasien yang alergi serta psikososial.

Tujuan: Mengetahui hubungan penggunaan antibiotik dengan tingkat kekambuhan ISPA pada balita.

Metode: Penelitian analitik observasional dengan cross-sectional, melibatkan 76 sampel dengan random sampling, analisis data menggunakan uji Chi Square.

Hasil: Hasil yang diperoleh penggunaan antibiotik terhadap balita ISPA sebanyak 53,95\%, balita mengalami kekambuhan sebanyak 46,34\% dan uji Chi Square diperoleh nilai $p$ value $0,004(p=<0,05)$.

Kesimpulan:Terdapat hubungan antara penggunaan antibiotik dengan tingkat kekambuhan ISPA pada balita.
\end{abstract}

Kata Kunci : Antibiotik, ISPA, Balita, Kekambuhan

\section{ABSTRACT}

Background:Antibiotic is an essence or a substance which used to prevent and treat an infection due to bacteria. In the United States of America there are 50 million unnecessary antibiotic prescriptions of 150 million prescriptions every year in which the use of antibiotics continues increasing which causes inappropriate drug usage, it will cause many problems in terms of effectiveness, drug effects, interactions, and economics aspect and drug abuse, thus, it causes many negative impacts such as quality and management of drug services, drug resistance, drug effects in patients, allergies to allergic patients and psychosocial.

The objective: To identify the relationship between antibiotic usage and recurrence rate of acute respiratory infection (ARI) in children under five years old.

Method: Observational analytical research with cross-sectional, which involves 76 samples with random sampling, the analysis of the data is using Chi Square Test.

Finding:The obtained results of antibiotics usage to children under five years old who infected by acute respiratory infection (ARI) is 53,95\%, they who have recurrence is 46,34\% and the obtained value of Chi square test is $\mathrm{p}$ value 0,004 ( $\mathrm{p}=<0,05$ ).

Conclusion: There is a relationship between antibiotic usage and recurrence rate of acute respiratory infection (ARI) in children under five years old.

Keywords : Antibiotic, Acute Respiratory Infection (ARI), Children under Five Years Old, Recurrence 


\section{PENDAHULUAN}

Obat merupakan salah satu faktor penting dalam pelayanan kesehatan. Penggunaan obat yang tidak tepat akan menimbulkan banyak masalah meliputi dari segi efektivitas, efek samping, interaksi, ekonomi dan penyalahgunaanobat (Pharmaceutical Care Network Europe, 2003).

Penyalahgunaan obat makin hari makin meningkat, sehingga mem- berikan banyak dampak negatif antara lain mutu dan pengelolaan pelayanan obat, resistensi obat, dampak efek samping pada pasien, alergi bagi pasien yang alergi serta dampak psikososial (Siswati, 2009).

The Center for Disease Control and Prevention menyebutkan di Negara Amerika Serikat terdapat 50 juta resep antibiotik yang tidak diperlukan dari 150 juta resep setiap tahunnya menyebabkan penyalahgunaan antibiotik semakintinggi (Centres for Disease Control and Prevention, 2015). Di negara Eropa menunjukkan bahwa penggunaan obat antibiotik terus meningkat yang didorong oleh peng-gunaan antibiotik yang tidak rasional (Lim, K.K. \& Teh C.C., 2012)

Menurut International Journal of Infection Controldi negara berkembang termasuk di negara Indonesia terdapat antibiotik yang didapat tanpa menggunakan resep sehingga individumenggunakan antibiotik secara bebas. Antibiotik digunakan dengandosis yang tidak tepat, tanpa indikasi, cara pemberian dengan interval waktuyang tidak tepat, dan lama pemakaian yang tidak tepat (WHO, 2008).

Antibiotik adalah golongan obat yang digunakan untuk terapi, pencegahan infeksi sehingga antibiotik digunakan jika ada infeksi atau untuk kepentingan profilaksis (pencegahan infeksi). Antibiotik merupakan obat yang banyak digunakan pada infeksi yang disebabkan oleh bakteri. Berbagai studi menemukan bahwa sekitar 40-62\% antibiotik digunakan secara tidak tepat antara lain untuk penyakit-penyakit yang sebenarnya tidak memerlukan antibiotik (Kemenkes RI. 2011).

Tingginya prevalensi penyakit ISPA serta dampak yang ditimbulkannya membawa akibat pada tingginya konsumsi obat bebas (seperti anti influenza, obat batuk, multivitamin) dan antibiotik. Angka kejadian ISPA termasuk pneumonia yang masih tinggi pada balita disebabkan oleh tingginya frekuensi kekambuhan ISPA pada balita. Penggunaan antibiotik pada infeksi saluran pernapasan akut, khususnya pada pasien usia bawah lima tahun yang merupakan penderita terbesar dari penyakit ISPA perlu mendapat perhatian khusus (Sugiarti, T., 2015).

Insiden ISPA anak di negara berkembang maupun negara yang telah maju tidak jauh berbeda, tetapi jumlah angka kesakitan di negara berkembang lebih banyak. Kematian ISPA biasanya terbatas pada saluran pernapasan atas saja, tetapi sekitar $5 \%$ juga melibatkan saluran perna- pasan bawah terutama pneumonia (Ikatan Dokter Anak Indonesia, 2008). Di Negara Indonesia, terdapat 4 juta orang meninggal akibat ISPA setiap tahunnya, 98\% kematian tersebut adalah bayi. Prevalensi ISPA di Negara Indonesia sebanyak 25,5\% dengan 16 provinsi di antaranya mempunyai prevalensi di atas angka nasional dan pneumonia sebanyak $2,1 \%$ ). ${ }^{9} \mathrm{Di}$ Provinsi Jawa Barat, angka kejadian ISPA pada balita yakni 4,62\% yang seharusnya perkiraan kasus secara nasional ditiap provinsi yakni 3,55\% (WHO, 2007). Berdasarkan data yang diperoleh dari Dinas Kesehatan Kota Tasikmalaya dan Puskesmas Cilembang Kota Tasik- malaya angka kejadian ISPA pada balita mengalami peningkatan dan merupakan salah satu penyakit terbanyak pada balita yakni sebesar 44\%. Puskesmas Cilembang Kota Tasikmalaya mela- porkan rekapitulasi tahunan, bahwa angka kejadian ISPA pada balita tahun 2016 sebanyak 2239 yang terdiri dari pneumonia, pneumonia berat, bukan pneumonia. Kejadian ISPA di Puskesmas Cilembang Kota Tasikmalaya merupakan salah satu penyebab utama kunjungan pasien sebanyak 67\%.Peneliti melihat data prevalensi ISPA di Indonesia dan Puskesmas Cilembang Kota Tasikmalaya masih cukup tinggi, oleh karena itu, peneliti berkeinginan untuk menelaah tentang "Hubungan Penggunaan Antibiotik dengan Tingkat Kekambuhan ISPA pada Balita di Puskesmas Cilembang Kota Tasikmalaya”.

\section{METODE}

Penelitian ini menggunakan penelitian observasional analitik dengan metode penelitian cross - sectional. Tempat pelaksanaan penelitian di Puskesmas Cilembang Kota Tasikmalaya. Pada penelitian ini didapatkan data 76 Balita ISPA bukan Pneumonia. Pada penelitian kali ini subjek penelitian berdasarkan randome sampling dengan memenuhi kriteria inklusi dan kriteria eksklusi. Pengambilan 
data untuk penelitian ini menggunakan data rekam medik.Pada penelitian ini menggunakan analisis korelasi digunakan Uji statistik Chi Square.

\section{HASIL DAN PEMBAHASAN}

Tabel 1. Penggunaan Antibiotik Pada Balita ISPA bukan pneumonia.

\begin{tabular}{|c|c|c|c|}
\hline No & $\begin{array}{c}\text { Penggunaan } \\
\text { Antibiotik } \\
\text { Pada Balita } \\
\text { ISPA bukan } \\
\text { Pneumonia }\end{array}$ & $\begin{array}{c}\text { Frekuensi } \\
(\mathrm{F})\end{array}$ & $\begin{array}{c}\text { Presentasi } \\
(\%)\end{array}$ \\
\hline 1. & Iya & 41 & $53,95 \%$ \\
\hline 2. & Tidak & 35 & $46,05 \%$ \\
\hline & Total & 76 & 100 \\
\hline
\end{tabular}

Berdasarkan hasil di atas dapat diketahui bahwa sebagian besar penggunaan antibiotik pada balita ISPA bukan pneumonia dalam penelitian ini sebanyak 53,95\%, selanjutnya yang tidak penggunaan antibotik pada balita ISPA bukan pneumonia sebanyak 46,05\%.

Penggunaan obat dikatakan rasional jika memenuhi kriteria yaitu tepat diagnosis, tepat indikasi penyakit tepat pemilihan obat, tepat dosis, tepat cara pemberian, tepat interval waktu, pemberian tepat lama, pemberian waspada terhadap efek samping (WHO, 2007).

Salah satu bentuk pembuatan resep yang tidak rasional adalah penggunaan obat, padahal indikasi penyakit diperlukan, seperti dalam penelitianini penggunaan antibiotik pada penderita ISPA bukan peneumonia. Semakin patuh respoden dalam melaksanakan tahap-tahap penetapan diagnosis ISPA. Faktor-faktor yang mempengaruhi penggunaan antibiotik terdiri dari faktor pembuatan resep, pembuatan obat, dan pasien. Faktor yang menentukan penggunaan obat oleh pembuatan resep dapat dipengaruhi oleh hal-hal yaitu tingkat pengetahuan tentang penggunaan antibiotik yang dimana rendahnya tingkat pengetahuan tentang penggunaan antibiotik dapat terjadi salah diagnosis dan kesulitan untuk membedakan infeksi bakteri atau virus. Ketersediaan sarana diagnostik dan pemeriksaan penun- jang, permintaan pasien, promosi obat, tingkat dan frekuensi supervisi pada hal ini dilihat dari tingat pengawasan apakah ketat atau tidak ketat dan frekuensi supervisi. Pengawasan oleh atasan dapat meningkatkan rasionalitas penggunaan antibiotik atau justru sebaliknya, dapat terjadi pemberian antibiotik yang kurang atau berlebihan akibat kekhawatiran pembuatan resep (Febiana Tia., 2012).

\section{Tabel II. Tingkat Kekambuhan Pada Balita ISPA bukan pneumonia.}

\begin{tabular}{|c|c|c|c|c|}
\hline No & & Rendah & Sedang & Tinggi \\
\hline 1. & $\begin{array}{c}\text { Tingat } \\
\text { kekambuhan } \\
\text { yang } \\
\text { menggunakan } \\
\text { antibiotik }\end{array}$ & $\begin{array}{c}19 \\
(46,34 \%)\end{array}$ & $\begin{array}{c}18 \\
(43,90 \%)\end{array}$ & $\begin{array}{c}4 \\
(9,76 \%)\end{array}$ \\
\hline 2. & $\begin{array}{l}\text { Tingkat } \\
\text { kekambuhan } \\
\text { yang tidak } \\
\text { menggunakan } \\
\text { antibiotik }\end{array}$ & $\begin{array}{c}29 \\
(82,25 \%)\end{array}$ & $\begin{array}{c}4 \\
(11,43 \%)\end{array}$ & $\begin{array}{c}2 \\
(5,71 \%)\end{array}$ \\
\hline
\end{tabular}

Berdasarkan tabel di atas bahwa balita ISPA yang menggunakan antibiotik dengan tingkat kekambuhan rendah adalah sebanyak 46,34\%, dengan tingkat kekambuhan sedang sebanyak 43,90\%, dengan tingkat kekambuhan tinggi sebanyak $9,76 \%$, sedangkan balita ISPA yang tidak menggunakan antibiotik mengalami tingkat kekambuhan rendah sebanyak $82,85 \%$, tingkat kekambuhan sedang sebanyak $11,43 \%$, dan tingkat kekambuhan tinggi sebanyak 5,71\%.

Tingginya prevalensi penyakit ISPA serta dampak yang ditimbul- kannya membawa akibat pada tingginya konsumsi obat bebas (seperti anti influenza, obat batuk, multivitamin) dan antibiotik. Angka kejadian ISPA termasuk pneumonia yang masih tinggi pada balita disebabkan oleh tingginya frekuensi kekambuhan ISPA pada balita. Penggunaan antibiotik pada infeksi saluran pernapasan akut, khususnya pada pasien usia bawah lima tahun yang merupakan penderita terbesar dari penyakit ISPA perlu mendapat perhatian khusus.

Dalam pedoman pengobatan, pilihan obat yang ada telah melalui proses tersebut dan dicantumkan sebagai obat pilihan utama (drug of choise), pilihan kedua dan seterusnya. Pengobatan rasional diperlukan karena pada pengobatan yang tidak rasional dapat menyebabkan pengobatan yang tidak aman, kambuhnya penyakit dan masa sakit 
memanjang. Juga membahayakan dan menimbulkan kekhawatiran pasien serta membe- ngkaknya biaya (Masduki, 2010).

Faktor-faktor yang dapat menye- babkan kegagalan terapi antibiotik salah satunya munculnya organisme resisten atau organisme yang menginfeksi berubah sehingga dapat menyebabkan kekambuhan pada penyakit tersebut (Tripathi, K. D. (2008).

Table III. Hubungan penggunaan antibiotik pada balita ISPA dengan tingkat Kekambuhan ISPA pada balita di Puskesmas Cilembang Kota Tasikmalaya periode 1 januari - 31 desember 2016

\begin{tabular}{cc}
\hline P-Value & ChiSquare \\
\hline 0.05 & 0.004 \\
\hline
\end{tabular}

Dari analisis yang telah dilakukan menggunakan korelasi Chi Squaremendapatkan hasil nilai Pvalue $0,000(P=<0,05)$ dengan sebesar 0.004 artinya Ho ditolak atau terdapatpengaruh yang signifikan antara hubungan penggunaan antibiotik dengan tingkat kekam- buhan ISPA pada balita di puskesmas cilembang kota tasimalaya periode 1 januari - 31 desember 2016.

Peresepan yang tidak tepat dapat berkontribusi dalam kejadian resistensi antibiotik. Sebesar 30\%-50\% indikasi terapi, pemilihan antibiotik atau durasi terapi antibiotik tidak tepat. Konsentrasi subterapetik dapat memicu resistensi antibiotik (Ventola, C.L., 2015). Terlepas dari kesalahan dan ketidaktepatan dalam pemberian terapi, hal tersebut akan berpengaruh pada meningkatnya biaya perawatan dan penurunan kualitas pelayanan rumah sakit. ${ }^{15}$ Frekuensi kesalahan peresepan yang terjadi terbanyak adalah kesalahan dosis (62 \%), memberikan reaksi alergi (20\%), terapi ganda (7\%) (Maksum, R., 2010).

The Centers for Disease Control and Preventionmenyebutkan bahwa terapi simtomatik untuk ISPA bukan pneumonia tidak merekomendasikan penggunaan antibiotik. Antibiotik sebagai obat untuk menanggulangi penyakit infeksi, penggunaannya harus rasional, tepat dan aman. Penggunaan antibiotik yang tidak rasional akan menimbulkan dampak negatif, seperti terjadi kekebalan kuman terhadap beberapa antibiotik, meningkatnya efek samping obat dan bahkan kematian. Penggunaan antibiotik dikatakan tepat bila efek terapi mencapai maksimal sementara efek toksis yang berhubungan dengan obat menjadi minimum, serta perkembangan antibiotik resisten seminimal mungkin (Morrison, M., J. 2004).

Pada kenyataannya, penggunaan antibiotik pada ISPA seringkali tidak rasional. Data Depkes tahun 2011 menunjukkan 60\% penderita ISPA mengkonsumsi antibiotik dengan tidak tepat yaitu terlalu banyak atau tidak sesuai dosis, lama konsumsi tidak tepat, peresepan obat tidak sesuai diagnosis, serta pengobatan sendiri dengan obat yang seharusnya didapat melalui resep dokter.

Terlalu sering mengkonsumsi antibiotik berarti membunuh seluruh kuman jinak yang bermanfaat bagi tubuh. Jika populasi kuman jinak yang bermanfat bagi tubuh terbasmi, keseimbangan mikroorganisme tubuh bisa terganggu, sehingga jamur yang tadinya takut oleh kuman-kuman yang ada di tubuh kita berkesempatan lebih mudah menyerang, maka dari itu menyebabkan kekambuhan atau menimbulkan penyakit yang baru (Tripathi, K. D., 2003).

Penggunaan antibiotik yang tidak sesuai dengan studi terapi akan meningkatkan dampak negatif, seperti terjadi kekebalan kuman terhadap beberapa antibiotik, meningkatkan kejadian efek samping obat, biaya pelayanan kesehatan menjadi tinggi. Atas dasar semua ini, penggunaan antibiotik perlu diatur agar dapat secara tepat diterapkan dengan pendekatan struktural. Apabila antibiotik digunakan secara luas di Rumah sakit atau pelayanan kesehatan lainnya dalam dosis yang tidak akuratdan waktu yang lama, maka akan resisten (Sastromibardja dan Herry S., 1997).

The Centers for Disease Control and Prevention menyebutkan bahwa pemberian terapi antibiotik yang kurang tepat dapat menimbulkan masalah resistensi dan potensi terjadinya kejadian efek samping sehingga diperlukan peran apoteker untuk mengevaluasi ketepatan penggunaan antibiotik. ${ }^{3}$ Meningkatnya kejadian resistensi antibiotik menjadi penyebab dalam perkembangan infeksi menjadi lebih parah, terjadinya komplikasi, waktu tinggal di rumah sakit yang menjadi lebih lama dan meningkatnya risiko kematian (Llor, C. \& Bjerrum, L., 2014).

Pemberian antibiotik yang kurang dosisnya tersebut menyebabkan resistensi bakteri terhadap obat tersebut yang akan menyebabkan pembiayaan 
kesehatan akan meningkat. Faktor-faktor yang mempengaruhi efek maksimal obat adalah penentuan dosis, cara dan lama hari pemberian yang tepat. Sifat farma- kokinetik dan farmakodinamik obat akan mempengaruhi besarnya dosis dan cara dan frekuensi pemberian sedangkan lama pemberian obat berdasarkan pada sifat penyakit tersebut seperti akut, kronis atau kambuh secara berulang (Isnaini, N., 2007).

Penyebab utama resistensi antibiotik adalah penggunaannya yang meluas dan irasional. Sekitar $80 \%$ konsumsi antibiotik dipakai untuk kepentingan manusia dan sedikitnya $40 \%$ berdasar indikasi yang kurang tepat, misalnya infeksi virus (Depkes RI. (2014).

Faktor-faktor yang dapat menyebabkan kegagalan terapi antibiotik salah satunya munculnya organisme resisten atau organisme yang menginfeksi berubah sehingga dapat menyebabkan kekambuhan pada penyakit tersebut (Tripathi, K. D., 2008).

Peresepan obat sesuai standar merupakan peresepan obat yang rasional yaitu mengeluarkan resep obat sesuai standar yang digunakan. Peresepan obat sesuai standar merupakan peresepan obat yang benar, jelas dan sesuai dengan kebutuhan pasien yang mempe- rtimbangkan jenis obat yang diberikan, dosis, lama pemberian, dan terjangkau untuk masyarakat (WHO, 2010).

Peresepan obat yang tidak tepat akan menghasilkan pengobatan yang tidak tepat, hal ini dapat menyebabkan dampak seperti terjadinya resistensi antimikroba, terjadinya efek yang tidak diinginkan, pengeluaran pembiayaan yang terlalu besar dan kekambuhan yang berulang akibat penggunaan obat yang diluar batas (WHO, 2010).

\section{KESIMPULAN}

1. Terdapat hubungan antara penggunaan antibiotik dengan tingkat kekambuhan ISPA pada balita.

2. Dalam penelitian ini semakin tinggi penggunaan antibiotik pada balita ISPA bukan pneumonia maka semakin banyak yang mengalami kekambuhan.

\section{SARAN}

1. Perlunya penelitian lebih lanjut tentang rasionalitas pengobatan pada penyakit ISPA, terutama pada pasien anak-anak.

2. Perlunya penelitian selanjutnya dengan penelitian yang berbeda tempat terutama setiap daerah yang dalam cakupan wilayah Negara Indonesia.

3. Perlunya penelitian selanjutnya apabila tertarik dengan penelitian yang sama disarankan untuk mengembangkan penelitian dengan menggunakan pendekatan yang berbeda seperti penelitian kulitatif, sehingga dapat melengkapi penelitian ini.

\section{DAFTAR PUSTAKA}

Anggraini, A.B., Opitasari, C., \& Sari. (2014). The use of antibiotic the use of antibiotics in hospitalized children patients in an Indonesian hospital. Health Science Journal of Indonesia, 5(1), 40-43.

Centres for Disease Control and Prevention. Antibiotic/ Antimicrobial Resistance, (2013). http:// www.cdc.gov/drugresistance/, accessed Februari, 62015

Depkes RI. (2014). Pedoman Program Pemberantasan Penyakit Infeksi Saluran Pernapasan Akut (ISPA) untuk Penanggulangan Pneumonia pada Balita. Jakarta: Departemen Kesehatan RI.

Febiana Tia. (2012). Kajian rasionalitas penggunaan antiboitik di bangsal anak RSUP Dr. Kariadi Semarang periode Agustus-Desember 2011. Laporan Karya Tulis Ilmiah Fakultas Kedokteran Universitas Diponegoro.

Ikatan Dokter Anak Indonesia (IDAI). (2008). Buku Ajar Respirologi anak, edisi pertama. Jakarta: Badan Penerbit Ikatan Dokter Anak Indonesia.

Isnaini, N., 2007. Analisis Utilisasi Resep Antibiotik Pasien Rawat Jalan Tingkat Pertama (RJTP) di Puskesmas Tebet Jakarta Selatan, Tahun 2005. Kesmas: National Public Health Journal 1, 266-274.

Kemenkes RI. (2011). Pedoman Umum Penggunaan Antibiotik, Jakarta: Kemenkes RI.

Lim, K.K. \& Teh C.C. (2012). A cross sectional study of public knowledge and attitude 
towards antibiotics in Putrajaya, Malaysia. Southern Med Review. 5 (2), 26-33.

Llor, C. \& Bjerrum, L. (2014). Antimicrobial resistance: risk associated with antibiotic overuse and initiatives to reduce the problem. Ther Adv Drug Saf., 5 (6), 229-41.

Maksum, R., Nurgani, A., Endang, P., 2010. Faktor yang mempengaruhi ketidak sesuaian pengunaan antibiotika dengan uji kepekaan di ruang intensif Rumah Sakit Fatmawati Jakarta tahun 2001-2002. Makara of health series 8 .

Masduki. (2010). Hubungan sikap dan persepsi dengan kepatuhan Dokter pada pengobatan rasional penyakit Ispa (infeksi akut saluran pernapasan atas) Di puskesmas kabupaten tulungagung. (tesis). UNS.

Morrison, M., J. (2004). Manajemen Pengobatan. Jakarta: EGC

Pharmaceutical Care Network Europe. (2003). PCNE Classification for Drug Related Problem, Pharmaceutical Care Network Europe Foundation.

Riset Kesehatan Dasar. (2013). Riset Kesehatan Dasar Badan penelitian dan Pembangunan Kesehatan kementrian Kesehatan Indonesia. Jakarta: Riset Kesehatan Dasar.

Sastromihardja dan Herry S. (1997). Penggunaan Antibiotik Yang Rasional, Cetakan I, Pendidikan Kedokteran Berkelanjutan Ikatan Dokter Indonesia, Jakarta.

Siswati. (2009). Analisis penggunaan antibiotika yang tidak rasional pada balita penderita bukan penumonia di kota Padang. Lembaga Penelitian Universitas Negeri Padang.

Sugiarti, T., Sidemen, A., Wiratmo, W. (2015). Studi penggunaan antibiotik pada pasien penyakit ispa usia bawah lima tahun di instalasi rawat jalan Puskesmas Sumbersari periode 1 Januari-31 Maret 2014 (study of antibiotics use on ari patients in under five years outpatient clinic, sumbersari faktor intrinsik dan ekstrinsik yang berpengaruh terhadap infeksi saluran pernapasan akut (ispa) pada balita. Pustaka Kesehatan. 3, 262-266.

Tripathi, K. D. (2003). Antimicrobial Drugs: General Consideration Essential of Medical Pharmacology
Fifth edition. Jaypee: Brothers Medical Publishers.

Tripathi, K. D. (2008). Essential of Medical Pharmacology ed 6th, Jaypee: Brother Medical Publisher LTD, New Delhi, pp. 667-808

Ventola, C.L. (2015). The antibiotic resistance crisis: part 1: causes and threats. P \& T : Apeerreviewed journal for formulary management. 40 (4), 277-83.

WHO. (2007). WHO Model Prescribing Information Drug Use in Bacterial Infection. Geneva: WHO, 14-17.

WHO. (2008). Pencegahan dan pengendalian infeksi saluran pernapasan akut (ISPA) yang cenderung menjadi epidem dan pandemi di fasilitas pelayanan kesehatan. diakses 05 Oktober 2016.

WHO. (2010). Management Sciences for Health. Drug and Therapeutics Committees: A Practical Guide, Geneva, Switzerland. 